\title{
Comparison of the Biological Behaviour of Human Dermal Fibroblasts seeded on 3D Printed Polylactic acid, Polycaprolactone and Polyethylene Terephthalate Scaffolds in vitro İnsan Dermal Fibroblastların 3B Baskılı Polilaktik asit, Polikaprolakton ve Polietilen Tereftalat
} İskelelerdeki Biyolojik Davranışlarının in vitro Karşılaştırılması

Ufkay KARABAY', R. Bugra HUSEMOGLU2', Mehtap Yuksel EGRILMEZ', Selma AYDEMIR 4 , Basak BAYKARA4, Serhat CAGIRAL', Hasan HAVITCIOGLU³ 'Dokuz Eylul University, Institute of Health Sciences, Department of Molecular Medicine, Izmir, Turkey ${ }^{2}$ Dokuz Eylul University, Institute of Health Sciences, Department of Biomechanics, Izmir, Turkey ${ }^{3}$ Dokuz Eylul University, Faculty of Medicine, Department of Orthopedics and Traumatology, Izmir, Turkey

Abstract: Regenerative medicine is a scientific field that improves and repairs diseased and injured tissues. Three-dimensional (3D) printing is an innovative technology that provides a new application field for regenerative medicine. 3D printed scaffolds by programming pore sizes and shapes serve as a temporary basis for cells until the natural extracellular matrix (ECM) is reconstructed. Dermal fibroblasts are mesenchymal cells located in the dermal skin layer that produce and organize ECM components. They play an essential role in skin wound healing and fibrosis. The aim of this study is to analyze the viability, adhesion, distribution, and collagen IV expression of human dermal fibroblasts (HDFs) seeded on 3D printed polylactic acid (PLA), polyethylene terephthalate (PET), and poly- $\varepsilon$-caprolactone (PCL) scaffolds in vitro. HDFs were seeded on scaffolds or tissue culture plastic plates as control and were cultured for 1 and 3 days. 3D PLA, PCL, and PET scaffolds were prepared using a custom made fused deposition modeling printer. The cell viability was measured by WST-1 assay on days 1 and 3 . The cell adhesion was evaluated by scanning electron microscopy (SEM). The distribution was analyzed by hematoxylin and eosin (H\&E) staining. Collagen IV expression was analyzed by immunohistochemical (IHC) staining. On day 1 , the viability of HDFs on the 3D PLA scaffolds was significantly higher than PCL scaffolds. On day 3, the viability of HDFs on 3D PLA and PET scaffolds was significantly higher than PCL scaffolds. SEM images showed that HDFs on 3D PLA scaffolds attached the surfaces, filled the interfiber gaps and maintained their tissue specific morphology on day 3 compared to PCL and PET scaffolds. Histological images stained with H\&E demonstrated that the distribution of HDFs on 3D PLA scaffolds was uniform on days 1 and 3. Collagen IV staining was more intense in HDFs on 3D PLA scaffolds on days 1 and 3. This study shows that 3D PLA scaffolds create a appropriate environment for cell viability, adhesion, distribution and may provide a high advantage in skin tissue regeneration.

Keywords: Human dermal fibroblasts, 3D printed scaffolds, Skin tissue regeneration

Özet: Rejeneratif tıp, hastalıklı ve yaralı dokuları iyileştiren ve onaran bir bilimsel alandır. 3 boyutlu (3B) baskı, rejeneratif tıbba yeni bir uygulama alanı sağlayan yenilikçi bir teknolojidir. Gözenek boyutları ve şekilleri programlanarak 3B baskı ile üretilen doku iskeleleri, doğal hücre dışı matriks (ECM) yeniden yapılandırılıncaya kadar hücreler için geçici bir destek görevi görmektedir. Dermal fibroblastlar, ECM bileşenlerinin üretimi ve düzenlenmesinde rol oynayan dermal deri tabakasında bulunan mezenkimal hücrelerdir. Dermal fibroblastlar yara iyileşmesi ve deri fibrozisinde temel rol oynayan hücrelerdir. Bu çalışmanın amacı, 3B baskılı polilaktik asit (PLA), polietilen tereftalat (PET) ve poli- $\varepsilon$-kaprolakton (PCL) doku iskelelerine ekilen insan dermal fibroblastlarının (HDF) canlıı̆̆, adezyonu, dağılımı ve kollajen IV ekspresyonlarının in vitro analiz edilmesidir. Doku iskelelerine ve kontrol grubu olarak doku kültür plastik plakalara ekilen HDF'ler 1 ve 3 gün boyunca kültüre edilmiştir. Doku iskeleleri özel tasarım birleştirmeli yığma modellemesi (FDM) ile 3B yazıcı kullanılarak hazırlanmıştır. Hücre canlılığı WST-1 ile, hücre adezyonu taramalı elektron mikroskobisi (SEM) ile, hücre dağılımı hematoksilen \& eozin (H\&E) ve kollajen IV ekspresyonu immünohistokimyasal (IHC) boyamalar ile analiz edilmiştir. 1. günde 3B PLA iskelelerindeki HDF'lerin canlılığı, PCL iskelelerindeki HDF'lerden istatiksel olarak anlamlı yüksek bulunmuştur. 3. günde ise, 3B PLA ve PET iskelelerdeki HDF'lerin canlılığı PCL iskelelerindeki HDF'lerden istatiksel olarak anlamlı yüksek tespit edilmiştir. SEM görüntüleri, 3B PLA iskelelerdeki HDF'lerin yüzeylere bağlandığını, fiberler arası boşlukları doldurduğunu, PCL ve PET iskelelerine kıyasla özellikle 3. günde dokuya özgü morfolojilerini koruduğunu göstermiştir. HDF'lerin 3B PLA iskelelerindeki dağılımı 1. ve 3. günlerde geniş yayılım göstermiştir. 3B PLA iskelelerindeki HDF'lerde kollajen IV boyamasının 1. ve 3. günlerde daha şiddetli olduğu gözlenmiştir. Sonuçlarımız, 3B PLA iskelelerinin hücre canlılığı, adhezyonu, dağıııı için uygun bir ortam oluşturduğunu ve deri rejenerasyonunda avantaj sağlayabileceğini göstermektedir.

Anahtar kelimeler: Dermal fibroblast, 3B Baskılı iskeleler, Deri rejenerasyonu

Correspondence Address : R. Buğra Hüsemoğlu,

ORCID ID of the author: U.K 0000-0001-8608-1865, R.B.H

Dokuz Eylul University, Institute of Health

Sciences, Department of Biomechanics, Izmir,

Turkey bugrahusem@gmail.com

0000-0003-1979-160X, M.Y.E 0000-0002-3570-1865, S.A

0000-0003-1263-9998, S.C 0000-0002-1295-1749, B.B 0000-

0002-4178-2235, H.H 0000-0001-8169-3539

Please cite this article in press at: KARABAY U., HUSEMOGLU R. B., EGRILMEZ M.Y., AYDEMIR S., BAYKARA B., CAGIRAL S., HAVITCIOGLU H., Comparison of the Biological Behaviour of Human Dermal Fibroblasts seeded on 3D Printed Polylactic acid, Polycaprolactone and Polyethylene Terephthalate Scaffolds in vitro, Journal of Medical Innovation and Technology, 2021; 3 (1):7-13 doi: 10.51934/jomit.957164 


\section{Introduction}

Dermal fibroblasts are mesenchymal cells that play a role in the regulation of the extracellular matrix (ECM) in the connective tissue by producing collagen and elastic fibres (1). They play a major role in wound healing and fibrosis (2). Following tissue injury, fibroblasts migrate to the wound site and are activated into proto-myofibroblasts by various chemokines and cytokines. These cells are then differentiated into myofibroblasts and deposite abundant ECM. During tissue repair, myofibroblasts undergo apoptosis due to lack of signals (3). However, tissue repair may progress insufficiently in diabetic wounds, pressure ulcers, burns, and wounds of autoimmune diseases. In this regard, patients with these type of diseases may need to be treated with cellular therapy. Advances in tissue engineering has led to be produced customized implants in many medical fields. However, the host response to implanted biomaterials can cause immune rejection. Therefore, biomaterials used as implants must be biocompatible, non-toxic and biodegradable. With the introduction of three-dimensional (3D) printed tissue scaffolds in the medical applications, patient-specific materials can be designed to mimic and improve the damaged tissue microenvironment.

Dermal fibroblasts are commonly used in 3D printed tissue scaffolds. Different biomaterials were used for tissue engineering applications, such as polylactic acid (PLA) (4), polyethylene terephthalate (PET) (5), and poly- $\varepsilon$-caprolactone (PCL) (6). PLA is a biocompatible, biodegradable, non-toxic, hydrophobic aliphatic polyester used in many biomedical and clinical applications (7). PET is a non-toxic and non-degradable polymer and can be used to keep cells and scaffolds stable due to its ability to remain without degrading for a long time (8). PCL is a biocompatible, biodegradable, slow degradation rate, and spinnability hydrophobic poly (a-ester) material (9). There is a lack of data comparing the adhesion properties of dermal fibroblasts seeded on 3D printed PLA, PET and, PCL scaffolds. The aim of this study is to analyze the viability, adhesion, distribution and collagen IV expression of human dermal fibroblasts (HDFs) seeded on 3D printed PLA, PCL, and PET scaffolds in vitro.

\section{Materials and Methods}

\section{HDF culture}

Adult HDFs were purchased from ATTC (USA). Cells were cultured in fibroblast growth medium (FGM) at $37^{\circ} \mathrm{C}$ in a humidified atmosphere containing $5 \% \mathrm{CO}_{2}$. The culture medium was changed every 3 days. Cells were used at passage 5 .

\section{D Printing of Scaffolds}

Scaffolds template $(\varnothing=4 \mathrm{~mm}$, thickness $=2 \mathrm{~mm})$ were designed using SolidWorks 2019 software and subsequently filled and sliced using and Slic3r 1.2.9 software to obtain cylindrical STL models. Briefy, clump generator software was used to create squared pores into a $3 D$ object in a "stl" file format. 3D-printed scaffolds were prepared from PLA (eSun Filament, Shenzhen, China), PCL (Ideaformer, Shenzhen, China) and the PET (eSun Filament, Shenzhen, China). The 3D printer was a customized system working by the mechanism of fused deposition modeling (FDM). Printing was performed by the custom made FDM printer, using a nozzle diameter of $0.3 \mathrm{~mm}$, a layer thickness of 0.2 $\mathrm{mm}$, a nozzle temperature of $210^{\circ} \mathrm{C}(\mathrm{PLA}), 140^{\circ} \mathrm{C}(\mathrm{PCL}), 210$ ${ }^{\circ} \mathrm{C}(\mathrm{PET})$, and a printing bed temperature of $60^{\circ} \mathrm{C}$. All scaffolds had a thickness of $0.3 \mathrm{~mm}$. Both layers were printed with three perimeter lines and rectilinear filling under an angle of $0-90^{\circ}$, applying a flow rate of $100 \%$. Printing speed was set to be $25 \mathrm{~mm} / \mathrm{s}$ for all materials. Prior to biological evaluations, printed scaffolds were sterilized by ethylene oxide.

\section{Cell Seeding on 3D Scaffolds}

Sterile scaffolds were immersed in FGM in the 96-well plate and incubated overnight in a humidified incubator $\left(37^{\circ} \mathrm{C}, 5 \% \mathrm{CO}_{2}\right)$ prior to cell seeding. Then, suspension of HDFs in FGM were seeded on the scaffolds at $4 \times 10^{4}$ cells per well and incubated in the same incubator for $4 \mathrm{~h}$ to allow cell attachment. Each well was completed to $150 \mu \mathrm{L}$ FGM in total volume. In order to eliminate the cells that do not attach to scaffolds, 16-24 hours after seeding the scaffolds were placed in another 96-well plate. HDFs with equivalent numbers were also seeded on tissue culture plastic plates without scaffolds as controls. All of 3D scaffolds were cultured for 1 and 3 days.

\section{Measurement of HDFs viability on 3D Scaffolds}

Cell proliferation activity on the scaffolds was measured by ready-to-use colorimetric WST-1 assay (Biovision, Milpitas, CA, USA) on days 1 and 3 after seeding of the cells. The assay principle is based upon the cleavage of the tetrazolium salt WST-1 to formazan by cellular mitochondrial dehydrogenases. The generation of the dark yellow coloured formazan is measured at $450 \mathrm{~nm}$ and is directly correlated to cell number. The measurement was performed according to the manufacturer's instructions by using a microplate reader (Biotek Synergy HTX, USA). 


\section{Cell vizualisation on 3D scaffolds}

HDFs on the 3D scaffolds cultured 1 and 3 days after seeding were fixed to evaluate the adhesion properties by scanning electron microscopy (SEM). The cell-scaffolds constructs were transferred to the 24-well plate, fixed in $4 \%$ paraformaldehyde, dehydrated with a graded series of ethanol concentrations of $60 \%, 70 \%, 80 \%$ and $99 \%(v / v)$. Then the scaffolds were wrapped in aluminum foil and dried in desiccator for 2 days (10). The scaffolds placed on the platform were plated with $5 \mathrm{~nm}$ gold for 20 minutes by the Q150R S (Quorum) instrument. Copper banding was then applied to the platform to eliminate charging effect. Images were taken by ZEISS Sigma 500 VP FE-SEM.

\section{Histological examination}

Cell-scaffold constructs were removed from the media, washed three times in PBS and fixed in $4 \%$ paraformaldehyde at $4^{\circ} \mathrm{C}$ for $24 \mathrm{~h}$. This was followed by a tissue processing procedure and embedded in paraffin and cut into $5 \mu \mathrm{m}$ thick sections. The sections were then stained with hematoxylin \& eosin (H\&E). The morphology, distribution, and ECM production of HDFs cultured on 3D printed PLA, PCL and PET scaffolds were examined under light microscope (Olympus, BX51 microscope) (11). In immunohistochemical (IHC) evaluation, $5 \mu \mathrm{m}$ thick sections were treated with type IV collagen primary antibody (bs 10423R, Bioss) and incubated at $4^{\circ} \mathrm{C}$ for overnight. Antigenic sites were visualised by diaminobenzidine solution and counterstained with hematoxylin. The images were taken with a light microscope (Olympus BX51 microscope) with X20 magnification $(12,13)$.

\section{Statistical analysis}

Statistical analyses were performed using SPSS 24 software program. The results were expressed as mean \pm SD. Two groups were compared using Mann Whitney $U$ test. A value of $p \leq 0.05$ was considered significant.

\section{Results}

\section{The viability of HDFs on 3D Scaffolds}

A higher viability of HDFs was observed on 3D PLA scaffolds with respect to $3 D$ PCL scaffolds on day 1 . The viability of HDFs on 3D PLA scaffolds was significantly higher than 3D PCL scaffolds on day $1(p=0,05)$ (Figure 1A). Also, a higher viability of HDFs was observed on 3D PLA and 3D PET scaffolds with respect to 3D PCL scaffolds on day 3.
The viability of HDFs on 3D PLA and 3D PET scaffolds was significantly higher than 3D PCL scaffolds on day $3(p=0,05)$ (Figure 1B).
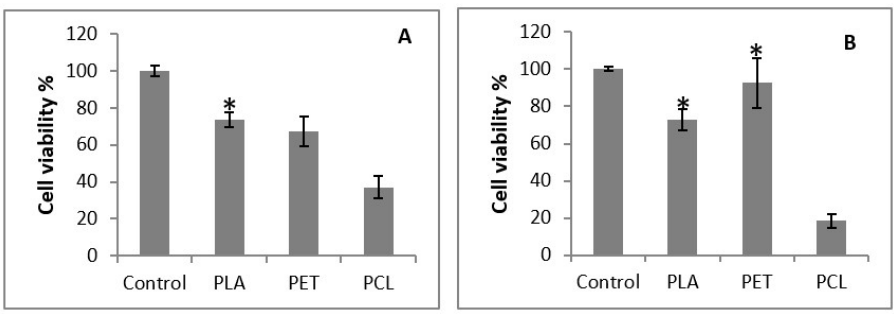

Figure 1. The viability of HDFs on 3D printed PLA, PET and PCL scaffolds on day 1 (A) and day 3 (B).

\section{The morphology of HDFs on 3D scaffolds}

The morphology of HDFs on 3D printed PLA, PET and PCL scaffolds was examined on days 1 and 3 and SEM images were taken to observe the attachment of HDFs to the scaffolds. SEM images showed that HDFs on 3D PLA scaffolds attached to the surfaces, filled the interfiber gaps, maintained their tissue specific spindle shape morphology, and exhibited cell-cell and cell-scaffold interactions on day 3 compared to 3D PCL and 3D PET scaffolds. However, HDFs could not be detected on $3 D$ PCL scaffolds on days 1 and 3 (Figure 2).

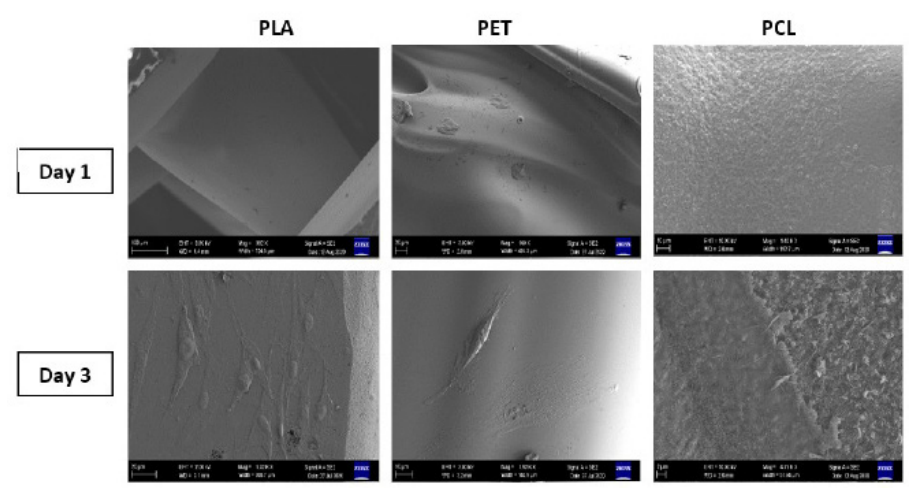

Figure 2. SEM images of 3D printed PLA, PET, and PCL scaffolds seeded with HDFs for 1 and 3 days.

\section{Histological analysis}

H\&E staining showed that spindle shape morphology was more prominent on 3D PLA scaffolds on days 1 and 3. 3D PLA scaffolds were with uniform distribution of HDFs compared to 3D PCL and 3D PET scaffolds on days 1 and 3. It was observed that HDFs on the 3D PET scaffolds clustered on days 1 and 3. HDFs on 3D PCL scaffolds demonstrated 
lower cell viability and round cell morphology on days 1 and 3 compared to other scaffolds. Moreover, HDFs on 3D PCL scaffolds showed individual distribution (Figure 3).

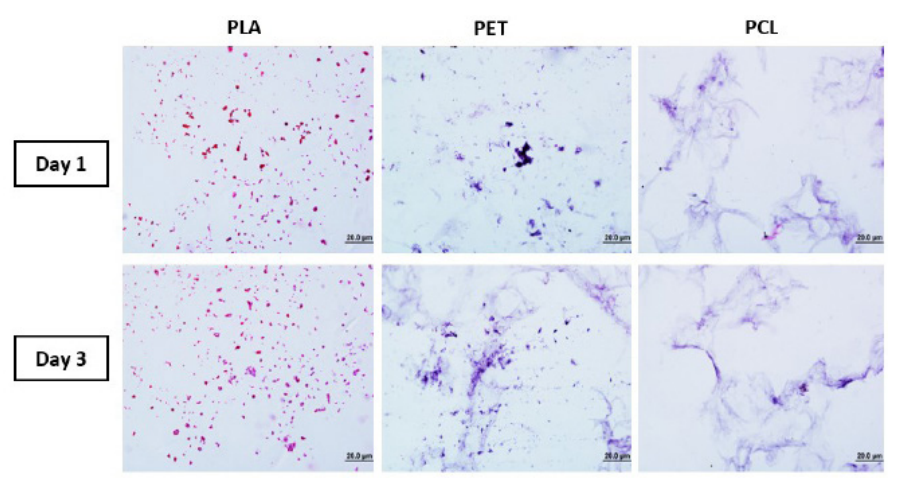

Figure 3. H\&E staining in HDFs seeded on 3D printed PLA, PET, and PCL scaffolds on days 1 and 3.

Immunoreactivity for type IV collagen was observed in HDFs on all 3D printed PLA, PET and PCL scaffolds on days 1 and 3. Type IV collagen expression in HDFs on 3D PLA scaffolds was stronger than in HDFs on 3D PET and 3D PCL scaffolds. Type IV collagen expression was similar for HDFs on 3D PLA on days 1 and 3. Immunoreactivity for type IV collagen was also similar in HDFs on 3D PET scaffolds on days 1 and 3 . However, type IV collagen immunoreactivity was lower on day 3 in HDFs on 3D PCL scaffolds compared to day 1 (Figure 4).

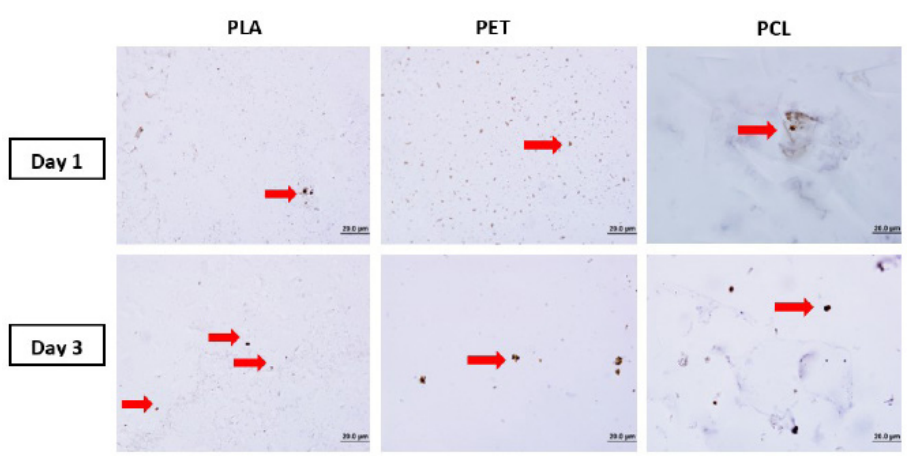

Figure 4. Type IV collagen staining in HDFs seeded on 3D printed PLA, PET, and PCL scaffolds on days 1 and 3.

\section{Discussion}

In the present study, we investigated the viability, adhesion. distribution and collagen IV expression of HDFs seeded on 3D printed PLA, PCL, and PET scaffolds in vitro. Our results showed that HDFs attached to 3D PLA scaffolds with a higher viability compared to $3 D$ PCL scaffolds on day 1. Also, the viability of HDFs on 3D PLA and 3D PET scaffolds was significantly higher than 3D PCL scaffolds on day 3.

PLA is a biodegradable aliphatic polyester, and has hydrophilic properties (14). It has extensively been used as a biomaterial for the human body because of its adsorbability and non-toxicity after degradation (15). In our previous study, we reported that HDFs continued to proliferate and attach to 3D PLA scaffolds on days 12 and 18 after seeding (16). Both our current and previous results show that PLA is biocompatible and safe in the short and long periods. PET has been used successfully in the medical field, for example for prosthetic vascular grafts, due to its high strength, biocompatibility, and long-term performance (17). Aladdad et al reported that 3D PET scaffolds were able to support human corneal stromal stem cell adhesion and proliferation (5). Our 3D PET results are consistent with this study. $\mathrm{PCL}$ is a biocompatible, biodegradable, and good elastic polymer with a low degradation rate when used alone (18). It has poor cell adhesion properties due to its hydrophobic properties. (18). Previous studies reported a low cell viability for 3D PCL scaffolds and suggested that this could be related to the hydrophobic characteristic of the PCL surface $(19,20)$. Our low cell viability results for PCL are consistent with these studies. However, another study showed a higher viability for HDFs seeded on 3D PCL scaffolds (21). These contradicting results might be due to the differences in scaffold manufacture. A recent study showed that there was no difference in the viability of MCF-7 breast cancer cells seeded on 3D PET and 3D PCL scaffolds (22).

HDFs on 3D PLA scaffolds show their specific spindle shape morphology on day 3 compared to $3 D$ PCL and 3D PET scaffolds. HDFs on 3D PLA scaffolds also show cellcell and cell-scaffold interactions as observed by SEM. H\&E staining demonstrated that spindle shape morphology was more prominent on 3D PLA scaffolds on days 1 and 3. 3D PLA scaffolds were with uniform distribution of HDFs compared to 3D PCL and 3D PET scaffolds on days 1 and 3 . This might be due to the hydrophilic characteristic of PLA which induces a more uniform distribution of cell attachment. Type IV collagen is a type of collagen found primarily in the skin within the basement membrane zone (23). Olsen et al showed the expression of type IV collagen in HDFs (24). A previous study emphasized the importance of type IV collagen expression in wound healing (25). In our study, immunoreactivity for type IV collagen was observed in HDFs on all 3D printed PLA, PET and PCL scaffolds. Type IV collagen expression in HDFs on 3D PLA scaffolds was stronger than in HDFs on 3D PET and 3D PCL scaffolds on days 1 and 3 .

Currently, there is no information comparing the viability, adhesion and distribution of HDFs on 3D printed PLA, PET and PCL scaffolds. Our study provides data for the biological behaviour of HDFs on these 3D scaffolds. Further 
studies are needed to design composite scaffolds and investigate the characteristics of these composite scaffolds in HDFs.

\section{Conclusion}

We demonstrate that 3D PLA scaffolds create a suitable environment for HDFs and may provide a high advantage for skin tissue engineering applications. Moreover, the higher viability, adhesion and the uniform distribution of HDFs on 3D PLA scaffolds suggest that they would have a promising potential in skin tissue regeneration.

\section{Acknowledgements}

The authors thank to Defne Ozturk (Izmir Biomedicine and Genome Center, Dokuz Eylul University, Izmir, Turkey) for technical support in SEM. 


\section{References}

1. Watt FM, Fujiwara H. Cell-Extracellular matrix interactions in normal and diseased skin. Cold Spring Harb Perspect Biol 2011;3(4):1-14.

2. Driskell RR, Watt FM. Understanding fibroblast heterogeneity in the skin. Trends Cell Biol 2015;25(2):92-9.

3. Witherel CE, Abebayehu D, Barker TH, Kara LS. Macrophage and fibroblast interactions in biomaterialmediated fibrosis. Adv Healthc Mater 2019;8(4):1-16.

4. Dorati R, Colonna C, Tomasi C, Genta I, Bruni G, Conti $B$. Design of 3D scaffolds for tissue engineering testing a tough polylactide-based graft copolymer. Mater Sci Eng C 2014;34(1):130-9.

5. Aladdad AM, Amer MH, Sidney L, et al. A thermoresponsive three-dimensional fibrous cell culture platform for enzyme-free expansion of mammalian cells. Acta Biomaterialia 2019;95:427-38.

6. Zhang G, Varkey M, Wang Z, Xie B, Hou R, Atala A. ECM concentration and cell-mediated traction forces play a role in vascular network assembly in 3D bioprinted tissue. Biotechnolog Bioeng 2020;117(4):1148-58.

7. Tyler B, Gullotti D, Mangraviti A, Utsuki T, Brem H. Polylactic acid (pla) controlled delivery carriers for biomedical applications. Adv Drug Deliv Rev 2016;107: 163-75.

8. Bridge JC, Aylott JW, Brightling CE, et al. Adapting the electrospinning process to provide three unique environments for a tri-layered in vitro model of the airway wall. J Vis Exp 2015;101:e52986.

9. Pinzon-Garcia AD, Cassini-Vieira P, Ribeiro CC, et al. Efficient cutaneous wound healing using bixin-loaded PCL nanofibers in diabetic mice. J Biomed Mater Res Part B Appl. Biomater 2017;105:1938-49.

10. Farrugia BL, Brown TD, Upton Z, Hutmacher DW, Dalton PD, Dargaville TR. Dermal fibroblast infiltration of poly $(\varepsilon-$ caprolactone) scaffolds fabricated by melt electrospinning in a direct writing mode. Biofabrication. 2013;5(2): 025001.

11. Huerta RR, Silva E, Ekaette I, El-Bialy T, Saldaña MDA. High-Intensity ultrasound-assisted formation of cellulose nanofiber scaffold with low and high lignin content and their cytocompatibility with gingival fibroblast cells. Ultrason Sonochem 2020;64:104759.

12. Chen WC, Wei YH, Chu IM, Yao CL. Effect of chondroitin sulphate $\mathrm{C}$ on the in vitro and in vivo chondrogenesis of mesenchymal stem cells in crosslinked type II collagen scaffolds. J Tissue Eng Regen Med 2013;7(8):665-72.

13. Griffin MF, Naderi N, Kalaskar DM, Seifalian AM, Butler PE. Argon plasma surface modification promotes the therapeutic angiogenesis and tissue formation of tissueengineered scaffolds in vivo by adipose-derived stem cells. Stem Cell Res Ther 2019;10(1):1-14.

14. Nagarajan S, Reddy BSR. Bio-absorbable polymers in implantation - an overview. J Sci Ind Res 2009;8:993-1009.

15. Theryo G, Jing F, Pitet LM, Hillmyer MA. Tough polylactide graft copolymers. Macromolecules 2010; 43:7394-7.

16. Karabay U, Husemoglu RB, Egrilmez MY, Havitcioglu H. 3D printed polylactic acid scaffold for dermal tissue engineering application : the fibroblast proliferation in vitro. Journal of Medical Innovation and Technology 2019;1(2):51-6.

17. Wang J, Huang N, Yang P, Leng YX, Sun H, Liu ZY, Chu PK. The effects of amorphous carbon films deposited on polyethylene terephthalate on bacterial adhesion. Biomaterials 2004;25:3163-70.

18. Zhang $X$ (Edited by). Science and Principles of Biodegradable and Bioresorbable Medical Polymers. In: Zhang X, Peng X, Zhang S. Synthetic biodegradable medical polymers: polymer blends. Woodhead Publishing, 2017;217-54.

19. Petretta M, Gambardella A, Boi M, et al. Composite scaffolds for bone tissue regeneration based on PCL and $\mathrm{Mg}$-containing bioactive glasses. Biology (Basel) 2021;10(5):398.

20. Patrício T, Glória A, Bártolo P. Mechanical and biological behaviour of PCL and PCL/PLA scaffolds for tissue engineering applications. Chem Eng Trans 2013;32:1645-50.

21. Hewitt E, Mros S, McConnell M, Cabral JD and Ali A. Melt-Electrowriting with novel milk protein/PCL biomaterials for skin regeneration. Biomedical Materials 2019;4(5): 055013. 
22. ÖG Geyik, Nalbant $B$, Hüsemoğlu RB, Yüce $Z$, Ünek $T$, Havitçıoğlu H. Investigation of Surface Adhesion of MCF-7 Cells in 3D Printed PET and PLA Tissue Scaffold Models. Journal of Medical Innovation and Technology 2019;1(2):45-50.

23. Hasegawa H, Naito I, Nakano K, Momota R, Nishida K, Taguchi T, et al. The distributions of type IV collagen alpha chains in basement membranes of human epidermis and skin appendages. Arch Histol Cytol 2007;70(4):255-65.

24. Olsen DR, Peltonen J, Jaakkola S, Chu ML, Uitto J. Collagen gene expression by cultured human skin fibroblasts. Abundant steady-state levels of type VI procollagen messenger RNAs. J Clin Invest 1989;83(3): 791-5.

25. Betz P, Nerlich A, Wilske J, Tübel J, Wiest I, Penning R, et al. The time-dependent rearrangement of the epithelial basement membrane in human skin wounds-immunohistochemical localization of Collagen IV and VII. Int J Legal Med 1992;105:93-7. 